\title{
Integrating global energy and climate governance: The changing role of the International Energy Agency
}

Harald Heubaum (SOAS) and Frank Biermann (Utrecht University)

\begin{abstract}
Despite the long-recognized interlinkages between global energy consumption and climate change, there has historically been only limited policy interaction, let alone integration, between the two fields. This compartmentalization is mirrored in scholarship, where much research has focused on the fragmentation of, respectively, global energy and global climate governance, but only little has been said about how these fields might be integrated. Our analysis of the International Energy Agency's (IEA) changing activities in recent years shows that governance integration - both within global energy governance and between global energy and climate governance - is now happening. The IEA has broadened its portfolio to embrace the full spectrum of energy issues, including renewable energy and climate change; it has built and is expanding key partnerships with both the UN climate convention and the International Renewable Energy Agency (IRENA); and it has become an authoritative advocate for the inter-related goals of a low-carbon transition and climate change mitigation. We show that these developments are not the result of a top-down plan, but have rather emerged through the Agency's various efforts to pursue its energy-centric mandate in a fastchanging global policy environment.
\end{abstract}

Keywords: Global energy governance; Global climate governance; Governance integration; Organizational change; International Energy Agency

\section{Introduction}

Since the $19^{\text {th }}$ century, global carbon dioxide emissions from fossil fuel combustion have grown from almost zero to over 31 gigatonnes annually, making energy consumption the most important source of greenhouse gas (GHG) emissions by far (IEA, 2013a, see also IPCC, 
2014). Despite the rise of renewable energy technologies, global dependence on coal, natural gas and oil for electricity generation, heating and cooling, transportation and industrial processes continues, with rapid rises of GHG emissions after a temporary slowdown in the wake of the 2008 global financial crisis (see e.g. BP, 2014). In addition, emissions are generated through the consumption and production of energy related to land use, notably in the clearing of land, the use of machines and oil-based plant fertilizer, and biofuel agriculture. As a consequence, global carbon dioxide emissions in 2012 were almost $60 \%$ higher than in 1990 (Peters et al., 2012). IPCC (2014) estimates suggest that if current emissions trajectories continue, it will be impossible to keep the rise in global average surface temperatures to $2{ }^{\circ} \mathrm{C}$ above pre-industrial levels (see also World Bank, 2014). ${ }^{1}$

Surprisingly, despite the long-recognized clear interlinkages between global energy consumption and climate change, ${ }^{2}$ there has historically been only limited policy interaction, let alone integration, between the two fields. For years, the climate convention process did not directly define the climate change problem as one largely about energy use. The 1997 Kyoto Protocol mentions energy only six times (of which twice in the Annex), there is no single mention of fossil fuels or coal, and oil and gas are only mentioned once in Annex A (UNFCCC, 1997). Many country delegations to official negotiations under the United Nations Framework Convention on Climate Change (UNFCCC) have historically been led by environment and foreign ministry representatives rather than officials from ministries responsible for energy or natural resources, underlining the policy-making disconnect between energy systems and their environmental impact. ${ }^{3}$

The same problem manifests at the national level. Although since the late 2000s some countries have sought to integrate responsibility for energy and climate policy by creating new ministries - prominent examples being Denmark's Ministry of Climate and Energy (created in 2007) and the UK's Department of Energy and Climate Change (created in 2008) - institutional separation remains the norm, and compartmentalization has been observed to

\footnotetext{
${ }^{1}$ Others have argued that the $2{ }^{\circ} \mathrm{C}$ goal - the oft-predicted threshold for dangerous climate change - is misleading and should be "ditched" as it is not scientifically meaningful and only politically motivated when emissions reduction progress to date does not match up with actual demands (Victor and Kennel, 2014). ${ }^{2}$ As one of our anonymous reviewers has pointed out, some analysts dispute the precise nature of the linkage between greenhouse gas (GHG) emissions and climate change. Although we recognize that there are complexities and uncertainties in climate science and possible outcomes of GHG emissions, our focus is on the process by which the IEA has added climate change to its portfolio.

${ }^{3}$ Interview with former senior UK negotiator to the climate convention, March 2015. The former negotiator also pointed out that due to a lack of interest in climate change and broader environmental concerns and, relatedly, an absence of environment ministries or equivalent, some countries (e.g. OPEC members) were for many years represented only through their energy and resource ministries. On renewable energy policies in Arab OPEC countries, see e.g. Atalay, et al. (2015).
} 
continue even after location of national responsibility for both fields in the same ministry. ${ }^{4}$ Moreover, although a growing number of governments have set national GHG emissions targets for the medium and long term, only few have also managed to design, let alone successfully implement, an energy policy in line with the acknowledged urgent need to decarbonize their economies. ${ }^{5}$

The problem is compounded by the institutional architecture of global energy governance (see e.g. Escribano, 2015; Goldthau and Witte, 2010; Van de Graaf, 2013a), which remains highly fragmented and ill-equipped to effectively address the core policy challenges related to both energy use and - the focus of our paper - its consequences for global climate change. Adopting a general conceptual frame developed by Biermann et al. (2009b; 2010), we define as the global governance architecture the "overarching system of public and private institutions that are valid or active in a given issue area," i.e. as comprising “organizations, regimes, and other forms of principles, norms, regulations and decisionmaking procedures" (Biermann et al., 2009b: 15). It was geopolitics and crisis that impelled the emergence in the second half of the $20^{\text {th }}$ century of a globe-spanning governance architecture in the energy field, when oil producer and consumer countries realized that in order to preserve their respective interests and reduce transaction costs they would be well served by forming organizations amongst like-minded members. ${ }^{6}$ Consequently, the onset of global climate change as an inescapable policy problem, and the need to decarbonize national energy systems if emissions reduction goals are to be met, have posed great challenges to an architecture whose main participants have largely been used to focusing on energy supply and demand dynamics rather than the environmental implications of fossil fuel combustion. ${ }^{7}$

And yet, as this article shows, significant moves towards the integration of energy and climate policy are emerging in unexpected ways. By analyzing the activities in recent years of the International Energy Agency (IEA), often considered the key organization in the fragmented landscape of global energy governance (see e.g. Leverett, 2010; Florini, 2011; Van de Graaf, 2012), we argue that the IEA is becoming an important and influential agent in

\footnotetext{
${ }^{4}$ Interview with national official involved in the IEA, August 2014.

${ }^{5}$ Denmark is a notable example of success. Apart from creating institutional synergies at ministerial level, and long being a leader on climate change mitigation, Denmark is working towards the goal of completely decarbonizing its energy system by 2050 through an integrated policy framework. According to the 2015 Climate Change Performance Index, Denmark has the world's best climate policy, followed by Sweden and the UK (Burck et al., 2015).

${ }^{6}$ This architecture may be described as bifurcated in that it initially split into oil producer and consumer country institutions, respectively, the two most prominent of these being the IEA (consumers) and OPEC (producers).

${ }^{7}$ Interview with IEA official, September 2014.
} 
the integration of global climate and energy governance. We focus on significant developments in three areas: the broadening of the IEA's issue portfolio, its increasing cooperation and partnership with the UNFCCC and the International Renewable Energy Agency (IRENA), and its growing advocacy for mitigating climate change and transitioning to a low-carbon future. We find that the IEA's increasingly consequential role in integration both within global energy governance and between the energy and climate governance fields derives not from a designed strategy or top-down plan, but emerges through its various efforts to pursue its energy-centric mandate in a complex and fast-changing global policy environment. That is, rather than a response to explicit demands from its member states, the IEA's role in integrating global energy and climate governance emerges through organizational change and adaptation impelled by today's global policy environment and novel ways in which it is exercising its organizational autonomy. ${ }^{8}$

\section{Methods}

\subsection{Literature review}

The compartmentalization between energy and climate change policy addressed above is also reflected in academic research and writing, with scholarships of environmental and energy governance largely evolving as if in two separate streams. While the International Relations (IR) literature addressing the management of global environmental issues dates back to the 1972 United Nations Conference on the Human Environment in Stockholm, the field did not fully "come into its own" until the late 1980s and 1990s (O'Neill, 2009: 7). It is during this time that IR scholars began to seriously address the formation of international environmental regimes and institutions (see e.g. Bernauer, 1995; Haas et al., 1993; Sprinz and Helm, 1999; Wettestad, 1999; Young, 1989). During the following two decades, the field grew further while also incorporating the new concept of global governance as different from an international, state-centered perspective. Scholars began conducting more research into the role played by international organizations, non-governmental organizations, transnational

\footnotetext{
${ }^{8}$ For a critical discussion of international organizations as autonomous actors in world politics, i.e. independent from their (state) members, see Barnett and Finnemore (1999, 2004). In contrast to Barnett and Finnemore's criticism, the analysis here shows how the IEA's changing role is in fact serving to overcome the collective action problems inherent to the fragmentation of global energy and climate governance and the divide between them. For an in-depth discussion of the autonomy of international bureaucracies as different from international organizations see Biermann and Siebenhüner (2009).
} 
advocacy networks and business actors (see e.g. Biermann et al., 2009a; Falkner, 2008; Ford, 2003; Oberthür and Stokke, 2011; Pattberg, 2007; Wapner, 1995). However, global climate change governance (as a particular kind of environmental governance) has arguably received the most scholarly attention in recent years, with a wide range of publications focusing on all aspects of the global climate governance architecture (see e.g. Biermann et al., 2010; Bulkeley et al., 2014; Bulkeley and Newell, 2010; Gupta, 2014; Held et al., 2011; Held et al., 2013; Helm, 2005; Helm and Hepburn, 2009; Hoffmann, 2011; Stevenson and Dryzek, 2014). An important strand of this literature has been an analysis of the fragmentation of the global climate governance architecture (see e.g. Biermann et al., 2009b; van Asselt, 2014; van Asselt and Zelli, 2014; Zelli, 2011).

Influenced by the 1970s oil crises, much of the earlier academic research on energy policy focused on questions of energy security and developments in world oil markets (see e.g. Adelman, 1973; Surrey, 1974). Research on global energy governance, defined here as the "international collective action efforts undertaken to manage and distribute energy resources and provide energy services" (Florini and Sovacool, 2009: 5239), has only emerged more recently (Cherp et al., 2011; Goldthau, 2011; Goldthau and Witte, 2010; Lesage et al., 2010; Meyer, 2013; Van de Graaf, 2013a). Subfields to this literature have endeavoured to analyze the role of specific organizations in a more complex world in which energy policy decisions are shaped by a multitude of actors across the Global North and South. These organizations include the IEA (see e.g. Colgan, 2009; Florini, 2010; Florini and Sovacool, 2009; Kohl, 2010; Leverett, 2010; Van de Graaf, 2012; Van de Graaf and Lesage, 2009), the Organization for the Petroleum Exporting Countries (OPEC) (see e.g. Colgan, 2014; Gately et al., 2013; Hochman and Zilberman, 2015; Wittmann, 2013) and, to a lesser extent, IRENA (see e.g. Urpelainen and Van de Graaf, 2015; Van de Graaf, 2013b).

Like its counterpart in global climate governance, the literature on global energy governance has identified the fragmentation of governance architectures as a key challenge (Leal-Arcas et al., 2015; Meyer, 2013; Van de Graaf, 2013a). Even more so than global climate governance, global energy governance consists of a large number of actors that are not fully interlinked or integrated. Although there is no core organization that unites all countries under a single roof, the IEA is often seen as occupying a key role in global energy governance as "the world's leading authority on energy economics" (Harvey, 2012b) and "the single most important institution for energy importing countries" (Colgan, 2009: 5). 
However, while fragmentation within global energy governance and within global climate governance is increasingly well-researched and understood, there are only very few publications today that have attempted to address existing gaps between the two architectures, taking an integrated look at the two fields which does not simply treat one as the addendum of the other (Falkner, 2014; Fouquet, 2013; Meyer, 2013; Zelli et al., 2013). ${ }^{9}$ This includes attempts to understand planet-wide transformation through the new, holistic paradigm of earth system governance which incorporates various different governance agendas, including energy, environment, food and water (Biermann, 2014).

What is missing beyond these accounts, however, is serious attention to the interlinkages and convergence between the global energy and climate governance architectures and the organizational and policy changes inherent to these. This is problematic given the closely intertwined nature of energy consumption and climate change, as well as the now widely accepted urgent need to address these issues in a joined-up fashion. This article is a contribution to addressing this gap. Our starting point is Van de Graaf's (2012: 241) call for an analysis of the evolving role of the IEA in global climate governance, something that has received scant attention so far. Our research is informed by the conviction that the possibility of resolving the key problem of climate change is served not, as some have argued, by a further fragmentation of the global energy governance architecture to "deemphasize linkages" (Meyer, 2013: 389), or indeed by shifting responsibility for addressing climate change away from the UNFCCC towards energy institutions, but instead by greater integration and linkages both within global energy governance and between the existing governance architectures in the climate and energy field.

\subsection{Concepts}

Building on Garcia et al. (2014) we define governance integration as a positive interaction of actors either within a governance architecture or between two (or more) different governance architectures which result in a convergence of policies and practices. ${ }^{10}$ Governance integration, whether within a governance architecture or between two different architectures, can only begin to occur if at least one of the actors involved changes or adjusts their approach

\footnotetext{
${ }^{9}$ In contrast, there is a wider range of publications addressing overlap between global climate governance and governance of global trade, biodiversity, etc. (see e.g. Epps and Green, 2010; Oberthür and Stokke, 2011; van Asselt, 2014).

${ }^{10}$ Garcia et al. refer to 'streams of governance' (e.g. fisheries and biodiversity governance) while we use the term 'governance architectures' as introduced above.
} 
and practices in ways that establish clear interlinkages with the approach and actions of another actor or group of actors. In the context of global energy governance, it would require at least one of the international organizations (such as the IEA) to break with established patterns and start behaving in ways that create linkages with other organizations, operating either within global energy governance or in global climate governance.

We argue that the changes in the IEA's approaches and activities are linked to forms of organizational innovation and change related to the Agency's engagement with a changing global policy environment. Organizational innovation and change are subjects of a vast literature, especially in management studies and sociology (see e.g. Damanpour, 1991; Damanpour and Schneider, 2006; Hage 1988; Hannan and Freeman, 1984; Levitt and March, 1988). Hage (1999: 599, see also Damanpour and Evan, 1984) defines organizational innovation as "the adoption of an idea or behaviour that is new to the organization." This innovation is further thought to consist of the three elements of "change, novelty and improvements in performance" within the organization (Lamprinakis, 2012: 96; see also Johannessen et al. 2001). Whilst a useful start, this literature's focus on innovation and changes in business practices in, predominantly, private sector organizations only goes so far for our purposes, that is, an analysis of the dynamics of policy change. This, however, is a central interest of the field of public policy, wherein policy change is generally understood as "an alteration in the commitment of a government to an objective" (Jones and Baumgartner, 2005: 117), that is, a change in the way governments address and manage policy problems, usually on the basis of regulatory and legislative change (see also Baumgartner and Jones, 1993; Howlett et al., 2009; John, 2003; Kingdon, 2002; Sabatier and Jenkins-Smith, 1993). For example, if the objective is to cut GHG emissions, the 'commitment' would come in the form of new legislation (e.g. enshrining national emissions targets or renewable energy support schemes in law) or the creation of new institutional arrangements (e.g. integrating responsibility for energy and climate policy in a new ministry). Such changes break with established patterns of governance, either adapting them to new external realities, or producing entirely new ways to deal with perceived problems.

We thus define organizational change as the change in the commitment of an organization to an objective, resulting in the adoption of new approaches and activities. It is these activities which we set out to trace and analyze below. The specific context we focus on, that of intergovernmental organizations such as the IEA operating in a changing policy environment, has not been well addressed by management studies, which typically focus on 
organizational, rather than policy change, or, indeed, by the public policy literature, which tends to focus on policy change at the national rather than the international level. Both literatures offer important insights which we draw on, along with those of the emergent literature on 'international bureaucracies' (Biermann and Siebenhüner, 2009). The core contribution of this article is the analysis of emergent integration between energy governance and climate governance, something largely neglected thus far in studies of both governance fields, especially given the long-standing separation between them highlighted above. Our analysis proceeds through a detailed study of the evolving activities through which the IEA is becoming an important and influential actor in advancing this integration. As such, the article is also a modest contribution to analyses of organizational change, although space constraints prevent us from a more in-depth theoretical discussion.

\subsection{Materials used and structure}

Our analysis draws on a variety of sources, including IEA publications, official website information, other academic studies, international media reports, and a series of elite interviews and background conversations with IEA and UNFCCC officials. Most of the interviews were granted on the condition of anonymity, and we therefore refer to them in a non-attributable way. In the following section, we lend empirical credibility to changes within the IEA through tracing the aforementioned three sets of activities: broadening the issue portfolio, increasing cooperation with the UNFCCC and IRENA, and a growing advocacy on behalf of a low-carbon transition. The next section discusses our findings in light of their implications for integration both within the field of energy governance as well as between energy and climate governance. We also discuss reasons for the IEA's observed organizational change and point to challenges for further governance integration. The article concludes with a look at implications for the IEA's role as an international organization.

\section{Results: The IEA as an adaptive organization}

The IEA was established in 1974 as an autonomous organization within the framework of the OECD. Its founding was a direct response to the 1973 oil crisis which had come as the consequence of both a reduction in oil production and an oil embargo imposed by OPEC members in answer to the Yom Kippur War fought between Israel and a coalition of Arab 
states led by Egypt and Syria. OECD countries, the world's major oil consumers at the time, were hit hard by the resulting oil price shock but they initially failed to react in a coordinated fashion, instead engaging in "competitive behaviors such as stockpiling and hoarding of oil reserves" which drove costs up even further (Florini and Sovacool, 2009: 5242). The IEA's original role was, thus, to prevent similarly uncoordinated measures in the face of future oil supply emergencies, helping OECD countries coordinate effective collective responses. Its mandate included a variety of measures intended to improve the energy supply security of its member countries, such as an information system closely tracking developments in oil markets and a framework for cooperation with oil companies. Critically, IEA members were required to hold emergency oil reserves "sufficient to sustain consumption for at least 60 days with no net oil imports" (Bamberger, 2004: 125), a limit since increased to 90 days.

Although not part of its formal mandate, towards the end of the Cold War, the IEA began to consider the impact of energy production and consumption on the environment, establishing initial links between energy and environmental policy. The first Ministerial Statement and Conclusions on Energy and the Environment was released by the IEA on 9 July 1985. Although the wording of this statement was quite general, it nevertheless included agreement on using energy more efficiently, combusting coal in an environmentally acceptable way, increasing the use of natural gas, and promoting renewable sources of energy. Environmental issues were kept on the agenda thereafter. In 1993, the Ministerial Declaration and Recommendation on Energy and the Environment urged ratification of the climate convention (for reproductions of the original documents see Scott, 1995, pp. 272-285). That same year, the organization officially expanded its scope beyond the primary objective of ensuring energy security to include as further goals economic development and environmental protection (Scott, 1994: 386). ${ }^{11}$ The IEA also made some early forays into alternative energy technologies such as nuclear power and renewables. Despite these developments, the IEA's role has not been sufficiently recognized, because of its historic image as "an institution mainly concerned with fossil fuels" (Van de Graaf, 2012: 240).

However, as our analysis below shows, the IEA has now effectively broadened into an organization which tackles the full range of energy technologies and policy issues. We focus in particular on three sets of activities. First, we show how the IEA has expanded its portfolio to embrace the full spectrum of energy issues, including renewable energy and

\footnotetext{
${ }^{11}$ A discussion of energy security is beyond the scope of this paper. For a good introduction to the concept, including the different definitions in existence today see, for example, Chester (2010), Kruyt et al. (2009), Sovacool and Brown (2010) and Yergin (2011).
} 
climate change. Second, we show that the IEA has built and is expanding a number of key partnerships with organizations in both the global energy governance and the global climate governance fields. Third, we show the IEA has become an authoritative advocate for the inter-related goals of shifting away from fossil fuels and taking action to mitigate climate change.

\subsection{Widening issue portfolio}

Since the creation of the IEA, the number of energy technologies and actors involved has proliferated, as has the number of energy policies enacted worldwide. Over the years, the IEA has been criticized for not sufficiently acknowledging this change. Much of this criticism has revolved around the Agency's perceived lack of unbiased attention given to renewables. For example, the Agency has been dismissed as "for the most part not qualified to represent the interests of renewable energy at the international level" because of its role in advancing the cause of fossil fuels and nuclear power (Hirschl, 2009: 4409). The creation of IRENA can be seen as at least in part a result of the frustration over the IEA's downplaying of the role of renewables (Van de Graaf and Lesage, 2009). It is undeniable that the IEA's earlier conservative projections for installed capacity (e.g. in wind energy) were later outstripped by actual developments. However, the IEA was hardly the only organization that got it wrong. The US Department of Energy, the World Bank and even the European Wind Energy Association - the European wind industry's own roof organization in Brussels - all underestimated actual installed capacity (REN21, 2012).

There is evidence that the IEA has taken on board some of the criticism in recent years, which may have been in part the result of the "salutary shock" (Van de Graaf, 2012: 239) provided by the creation of IRENA as a potential rival organization. Renewable energy plays a much bigger part of the Agency's issue portfolio today than ten years ago. It is now addressed by a separate Division and in 2011, the IEA established the Renewable Energy Industry Advisory Board (RIAB) to enhance links between the Agency and leading renewable energy industry stakeholders. IEA reports which acknowledge the rapid scaling up and increasing cost competitiveness of renewable energy sources such as onshore wind and solar photovoltaics are now issued on a regular basis (see e.g. IEA, 2010; IEA, 2012a; IEA, 2014a). The change towards a more positive outlook is perhaps best illustrated by two solar technology reports published in late 2014 which together spell out an ambitious vision for 
solar energy to become the world's largest electricity source by 2050 and contribute to a significant reduction in $\mathrm{CO}_{2}$ emissions, the core goal of global climate governance (IEA, 2014b; IEA, 2014c).

In part, these efforts are in line with the Agency's moves since the mid-2000s to expand its issue portfolio by gathering more statistics on electricity production, trade and consumption on a monthly basis for all OECD member countries, and publish reports on various aspects of electricity markets. Ahead of the launch of the IEA's 2014 Energy Technology Perspectives report, IEA Director Maria van der Hoeven argued that rather than oil, it is electricity which "is going to play a defining role in the first half of this century as the energy carrier that increasingly powers economic growth and development" (IEA, 2014d). With the growing importance of renewables in electricity generation, it is only natural to devote more attention to the issue. ${ }^{12}$ This is all the more so considering that all of the IEA's member countries have either moved to aggressively expand their domestic renewable energy portfolios or are planning to do so. Another important reason for the greater emphasis on renewables, however, has been the better staffing and resourcing of work on issues other than fossil fuels, in line with the changing priorities amongst IEA member countries. ${ }^{13}$ For example, both the Agency's renewables and energy efficiency units have grown in recent years, resulting in a more expansive gathering of statistics, more expert workshops in both member and partner countries, and publication of a growing number of in-depth reports.

Alongside its growing work on renewables, the Agency has increasingly focused on global climate change. Scarcely an issue in the infant days of global energy governance, climate change has since become one of the determinants of a modern, $21^{\text {st }}$ century energy policy. Like its member countries, the IEA has had to respond and adjust to this change. ${ }^{14}$ In contrast to its earlier work, the organization significantly expanded its focus following the 2005 G8 summit at Gleneagles (Florini and Sovacool, 2009: 5243). The IEA gathers $\mathrm{CO}_{2}$ emissions statistics, maintains a database on GHG emissions policies undertaken by member states and since 2008, all World Energy Outlooks (WEO) - the IEA's annual flagship

\footnotetext{
${ }^{12}$ While there is a wider range of low-carbon technologies, including nuclear power, we focus on renewables. This is because the recent changes in the IEA's approach discussed here are significantly more pronounced with regards to renewables than nuclear power or, for example, energy efficiency, both of which have been a significant part of the Agency's portfolio for much longer. However, it should be noted that, as the '2015 Technology Roadmap: Nuclear Energy', jointly published by the IEA and the OECD's Nuclear Energy Agency (NEA) states, nuclear energy has a prominent role in the decarbonization of power systems, emphasizing that under the IEA's $2^{\circ} \mathrm{C}$ scenario, "global installed capacity would need to more than double." We thank an anonymous reviewer for this point.

${ }^{13}$ Interview with national official involved in the IEA, August 2014.

${ }^{14}$ Interview with IEA official, September 2014.
} 
publication - have devoted substantial and growing attention to climate change. ${ }^{15}$ Critically, WEOs fall under the editorial authority of IEA Chief Economist Fatih Birol, a vocal advocate of acting on climate change (see below). This helps in part to explain why the WEO would focus as much on climate change even when the issue had slipped down the international policy agenda during the global financial crisis and its aftermath. Moreover, as one IEA official pointed out, there is little editorial interference from member states with the organization's reports, although country representatives are usually invited to provide comments, input and suggestions. ${ }^{16}$ Thus, while the interests of member countries are important in determining the Agency's overall direction, a certain degree of flexibility and culture of independent research also give IEA officials a chance to pursue more independent agendas and, as in the case of climate change, help reinvigorate the debate. ${ }^{17}$

Over time, the Agency has become "better at doing climate work," adding a "clear climate lens" to its assessments. ${ }^{18}$ This is also reflected in the WEO Special Reports which have highlighted clear linkages between the energy and climate policy fields. In 2013, the IEA published "Redrawing the Energy-Climate Map," which defined changes in the energy sector as the "key to limiting climate change" and proposed a number of energy policy solutions to "help keep the door open to the $2^{\circ} \mathrm{C}$ target through to 2020" (IEA, 2013a). This was followed by the 2014 Energy, Climate Change and Environment Insight Report presented to delegates at the $20^{\text {th }}$ Conference of the Parties (COP 20) to the UNFCCC in Lima. In June 2015, the Agency published a WEO Special Report on climate change ahead of COP 21 in Paris, which, explicitly emphasizing energy use and climate change as inextricably linked, spelled out a number of key steps needed from an energy perspective to achieve success at the UN climate talks and beyond (IEA, 2015a). A stakeholder meeting presenting the preliminary conclusions of the report in early March 2015 was attended, according to IEA officials, by all the key players in the global climate policy arena, reflecting the IEA's convening power and its newfound "weight in the climate debates." 19

Although the number of IEA staff working specifically on environmental issues is still quite small and large parts of the Agency "go on cheerfully without addressing climate

\footnotetext{
${ }^{15}$ We define substantial attention as devoting at least one of the major segments/ parts of the WEO to climate change. The WEO 2007 already addressed climate change and GHG issues but it did so in a more ancillary fashion. The change to the WEO 2008 (and WEOs thereafter) is significant.

${ }^{16}$ Interview with IEA official, June 2015.

${ }^{17}$ Interview with IEA official, March 2015.

${ }^{18}$ Interview with former senior UK negotiator to the climate convention, March 2015.

${ }^{19}$ Interview with IEA official, March 2015.
} 
change directly," ${ }^{20}$ what is important for our analysis is how major IEA units, such as those working on renewables, energy efficiency, energy technologies, electricity markets, carbon capture and coal, all increasingly address climate change and GHG emissions as a routine part of their work. In part this is a consequence of climate change considerations becoming gradually more prominent in these different energy issue areas. ${ }^{21}$ Another factor, interestingly, is the relatively high staff turnover. Permanent IEA contracts are rare and the majority of staff turns over every five to six years, resulting in the average age of mid-level staff in the late 30 s and early 40s. As one IEA official put it, the Agency may not pursue a conscious strategy of recruiting staff with knowledge of climate policy and an understanding of its connections with energy policy-making, but the inflow of younger experts who have been more exposed to these issues than their predecessors has nonetheless expanded the IEA's in-house expertise. ${ }^{22}$ In addition to such internal rebalancing of its issue portfolio, the Agency has moved to build bridges between the energy and climate governance architectures, which we turn to next.

\subsection{Building partnerships}

Since 2007, the IEA has supported global climate negotiations by organizing workshops, seminars and side events at conferences of the parties, which have facilitated the sharing of information and have helped build a better understanding of technical issues amongst country delegations. ${ }^{23}$ In September 2012, the IEA and the UNFCCC Secretariat signed a Memorandum of Understanding aimed at reinforcing "mutual efforts to promote clean energy and combat climate change" (IEA, 2012b). Both organizations would engage in a closer exchange, with the UNFCCC taking responsibility for the overall governance framework of climate change mitigation and adaptation and the IEA contributing its experience in energy policy and statistics within this framework.

Specifically, cooperation has developed along five major lines. First, the IEA supports the UNFCCC Secretariat in its efforts to establish reliable GHG emissions inventories

\footnotetext{
${ }^{20}$ Interview with IEA official, June 2015.

${ }^{21}$ These changes in the global policy environment manifest themselves not just in the IEA, as we discuss here, but at all levels of political authority and across all jurisdictions, for example through climate change laws and action plans, carbon taxation, emissions trading schemes, renewable energy acts and a wide range of other laws, regulations and policies. For an in-depth review of relevant legislation in countries around the world, see Nachmany et al. (2014).

${ }^{22}$ Interview with IEA official, June 2015.

${ }^{23}$ At COP 20 in Lima alone, the IEA hosted, co-hosted or participated in 19 different events.
} 
through an expert review of emissions data - a core function of the climate convention. The data provided to the Secretariat by country parties is compared with and verified through emissions data provided by the IEA. ${ }^{24}$ Second, the IEA plays a role in the UNFCCC's expert review process in relation to climate policy measures adopted by country parties to the climate convention. As the bulk of GHG emissions is tied to energy use, the majority of climate policy is necessarily also energy policy. Third, the IEA has provided input to the technical examination process, specifically the UNFCCC's Workplan on Enhancing Mitigation Ambition (Decision 1/CP.17) with the goal of scaling up decarbonization efforts in the pre-2020 period. IEA experts have participated in the Workplan's Technical Expert Meetings on issues ranging from energy efficiency and renewable energy sources to carbon capture and storage. Fourth, the IEA is also involved in the UNFCCC's Technology Mechanism (Decision 1/CP.16) and its two components, the Technology Executive Committee and the Climate Technology Centre and Network, both of which aim to enhance technology development and North-South transfer. This cooperation happens through the multilateral, public-private Climate Technology Initiative (CTI), an Implementing Agreement under the IEA. For example, the CTI's Private Financing Advisory Network seeks to help mobilize private capital in support of climate -friendly, clean energy businesses operating in developing countries. Finally, the Climate Change Experts Group, jointly hosted by the IEA and the OECD, provides technical input into the UNFCCC process although it is separate from the climate convention. It convenes two meetings per year between government, private sector and civil society representatives which are also attended by the UNFCCC, organizes side events at conferences of the parties and the annual Bonn climate change conferences, and regularly publishes policy papers on issues relevant to the climate negotiations. ${ }^{25}$

In addition to these formal and publicly visible activities, much of the collaboration is of a more informal nature, built on routine interactions between IEA, UNFCCC and OECD member country officials. For example, Paul Watkinson, Head of the Climate Negotiation Team in France's Ministry of Ecology, Sustainable Development and Energy and a key player in preparing COP 21, was "regularly in and out of the IEA" having built a "close

\footnotetext{
${ }^{24}$ This and following based on interview with UNFCCC official, March 2015.

${ }^{25}$ There are several mechanisms of cooperation between the IEA and the UNFCCC, for example through the Global Fuel Economy Initiative which is also tied in with the G20 and the UN's Post 2015 Development Agenda. The examples discussed here are intended to illustrate the more structured instances of engagement.
} 
relationship" with experts at the Agency. ${ }^{26}$ The IEA has also involved UNFCCC officials in shaping the WEO Special Reports through meetings at IEA headquarters in Paris. ${ }^{27}$

Connected to this increasingly close cooperation have been the IEA's moves to build closer links with IRENA. IRENA was founded by a number of IEA member countries led by Germany to push for an independent intergovernmental organization focused exclusively on renewable energy based on the perception of the IEA as captured by powerful fossil fuel and nuclear interests and biased against renewables (Van de Graaf, 2013b). Despite the IEA's unease over the creation of IRENA, understood as a competing organization, the activities of recent years reflect increasing cooperation and collaboration.

In early 2012, only three years after the creation of IRENA, the organizations signed an official partnership agreement, targeting the development and publication of the IEA/IRENA Global Renewable Energy Policies and Measures Database, ${ }^{28}$ collaboration in technology and innovation, and the sharing of renewable energy statistics. Commenting on the agreement, IRENA Director General Adnan Z. Amin declared the Agencies to be "natural partners in the global quest to increase the deployment of renewable energy" (IRENA, 2012). Since then, the organizations have held joint workshops and published a number of energy technology briefs, for example on solar photovoltaics and electricity storage. The technology briefs are published jointly by IRENA and the IEA's Energy Technology Systems Analysis Programme (ETSAP). In January 2015, IEA Executive Director van der Hoeven was a featured guest speaker at IRENA's Fifth Assembly alongside UNFCCC Executive Secretary Christiana Figueres. Two months later she praised the "good cooperation" between the IEA and IRENA at the Berlin Energy Transition Dialogue (van der Hoeven, 2015).

This seemingly rather harmonious relationship between the two Agencies can also be explained by the organizational differences that have remained between them (see Meyer, 2013). Unlike IRENA, the IEA takes a more holistic view of the energy system, underpinned by its extensive data-gathering and analysis across the whole range of energy issues, whereas IRENA is an organization dedicated to promoting renewables (Urpelainen and Van de Graaf, 2015). The differing mandates allow for a de-facto division of labor between the two organizations, even if this does not mean that rivalry between them has ended altogether. ${ }^{29}$

\footnotetext{
${ }^{26}$ Interview with IEA official, March 2015.

${ }^{27}$ Interview with UNFCCC official, March 2015.

${ }^{28}$ The database can be accessed at http://www.iea.org/policiesandmeasures/renewableenergy/

${ }^{29}$ Interview with IEA official, June 2015.
} 


\subsection{Advocating change}

The third set of activities has been a shift in the IEA's approach from one largely focused on gathering and analyzing energy statistics to one which also openly advocates particular energy choices. This is perhaps the most important and yet often overlooked change the IEA has undergone in the last few years. Criticized until recently as too favorable towards oil, coal and gas and employing "a deliberate method to hedge ever increasing profits for the conventional energy sector" (Murray, 2009), the Agency has restyled itself as an influential global advocate on behalf of the transition to a low-carbon future and aggressive climate change mitigation. This reorientation is reflected in the approach taken by leading figures within the organization, who have used their high-profile positions to advocate change. Among them are the IEA's Executive Director Maria van der Hoeven and the IEA's Chief Economist, Fatih Birol, who will follow van der Hoeven as Executive Director in September 2015. Both were not natural proponents of a low-carbon, climate change agenda but rather grew into their new roles over time. ${ }^{30}$

Ahead of the $3^{\text {rd }}$ Clean Energy Ministerial held in London in April 2012, van der Hoeven, a former Dutch Minister of Economic Affairs, warned that the world's "addiction to fossil fuels grows stronger each year. Many clean energy technologies are available but they are not being deployed quickly enough to avert potentially disastrous consequences. [...] The current state of affairs is unacceptable precisely because we have a responsibility and a golden opportunity to act [on climate change]" (Harvey, 2012). Commenting on the $18^{\text {th }}$ Conference of the Parties to the climate convention in Doha, Qatar, van der Hoeven emphasized "the need to rapidly transition to a more secure, sustainable global energy system" in which "carbon emissions must be dramatically reduced" (IEA, 2012c).

Birol, a former statistician at the OPEC Secretariat, used similar language to position the IEA and its 2011 World Energy Outlook in the climate change debate. Following the report's release in November 2011 shortly before the conference of the parties in Durban, he chided governments for their insufficient, non-legally binding emissions pledges, arguing that "with current policies in place, global temperatures are set to increase 6 degrees Celsius, which has catastrophic implications. [...] If as of 2017 there is not a start of a major wave of new and clean investments, the door to 2 degrees will be closed" (Westall and Dahl, 2011). Birol also helped position the Agency at the forefront of the campaign against fossil fuel

\footnotetext{
${ }^{30}$ Interview with IEA official, September 2014.
} 
subsidies, a critical step towards leveling the energy playing field for renewable energy sources trying to gain a foothold in the market. As early as 2009, the G20, based on data provided by the IEA, called for a phasing out of such subsidies in the "medium term" (Mason and Ennis, 2009).

Speaking to The Guardian in early 2012, Birol emphasized that "energy markets can be thought of as suffering from appendicitis due to fossil fuel subsidies [...] undermining the competitiveness of renewables," adding that such subsidies "are a hand brake as we drive along the road to a sustainable energy future" (Clark, 2012). In 2014, he warned against both the growing global use of emissions-intensive coal and continued fossil fuel subsidies, arguing that "there is a need to change course in a dramatic way" (Beckman, 2014). Making a similar case, van der Hoeven argued that "massive investments in low-carbon technologies renewable energy and energy efficiency - are needed in the power sector if we are to keep temperatures from rising more than 2 degrees" above pre-industrial levels (Energy Next, 2014). Presenting new IEA data in March 2015 which indicated a stalling of global GHG emissions from the energy sector in 2014 (albeit at a historically high level), Birol called climate change "the most important threat facing us today." He went on to argue that the new data would provide "much-needed momentum to negotiators preparing to forge a global climate deal in Paris in December" (IEA, 2015b). Most recently, at the June 2015 launch of the WEO Special Report on climate change ahead of the Paris negotiations, van der Hoeven pointed to the IEA's own work in making the case for international action. "As IEA analysis has repeatedly shown that the cost and difficulty of mitigating greenhouse gas emissions increases every year, time is of the essence" she urged (IEA, 2015c). Birol was unequivocal in establishing the connection between energy and climate change governance, arguing that "any climate agreement reached at COP21 must have the energy sector at its core or risk being judged a failure" (IEA, 2015c). We discuss the implications of such advocacy by prominent IEA figures below, but note here how it reflects a significant contrast to conventional understandings of the role of the IEA in international policy as essentially limited to global energy governance.

\section{Discussion and policy implications}

Our analysis has identified a number of reasons for the IEA's observed organizational change. First, as renewable sources have become more important in global electricity provision (IEA, 
2014a), the IEA has expanded its activities in relation to these as part of its mandate.

Although organizational competition following the creation of IRENA may have been seen as one of the reasons stimulating the IEA's greater focus on renewables, our analysis shows that the two organizations have become increasingly cooperative, working closely together in a number of different forums. In other words, we emphasize partnership, rather than competition as the key dynamic. Second, and relatedly, to varying degrees all IEA member countries have pursued policies aimed at expanding renewable energy sources in recent years and all have had to address global climate change as one of the $21^{\text {st }}$ century's key domestic and foreign policy challenges. The shift in the IEA's focus, therefore, has to be seen as situated within these developments. ${ }^{31}$ Third, however, the observed new approaches and activities are not merely an agent's response to its principals' (member countries') directives, but have also been powerfully driven by key 'policy entrepreneurs' within the organization. It is as part of pursuing the IEA's mandate in today's complex and fast-changing global policy environment that leading figures in the Agency, such as Fatih Birol and Maria van der Hoeven, are emphasizing the growing importance of mitigating climate change and transitioning to low-carbon energy systems, advocating more forcefully on behalf of these interconnected agendas. At the same time, IEA units such as the renewables, energy efficiency and electricity market units, etc. are increasingly integrating climate change issues into the regular work. This is not to say the latter is a consequence of the former, but that the salient context for both is the rising prominence of climate change issues in domestic and international agendas, making these increasingly unavoidable for both the organization's senior management as well as its constituent units. In addition, the comparatively high staff turnover which has seen younger experts joining the IEA's various units, has led to a gradual introduction of a better understanding of the interconnections between energy and climate policy. Finally, taken together, the IEA's moves can also be seen as an attempt to maintain its role as the leading international organization in the energy field. As one IEA official put it, if the organization ignored climate change as a key determinant of $21^{\text {st }}$ century energy policies and did not seek to play an active role in addressing the problem, it "would be abdicating itself and render itself irrelevant in the energy debate."32

The change in the role of the IEA through the three sets of activities outlined in this paper - broadening its issue portfolio, partnering with the UNFCCC and IRENA, and

\footnotetext{
${ }^{31}$ Interview with IEA official, September 2014.

${ }^{32}$ Interview with IEA official, June 2015.
} 
advocating policy change - has a number of important implications for both global energy governance and the integration between global energy and global climate governance. First, the further widening of the IEA's portfolio cements the Agency's position as the leading international organization in the energy field. No other organization within the current global energy governance architecture can claim to credibly cover the entire spectrum of relevant issues - from oil and gas markets to energy efficiency, renewable power, GHG emissions and climate policy - with as much authority and wide distribution as the IEA.

Second, the IEA's increased data collection and more positive outlook on renewables helps to build a stronger case for a transition away from fossil fuels and enables greater integration within global energy governance through a close cooperation with IRENA. If, following Van de Graaf (2013b: 18), the creation of IRENA in 2009 was meant to lead to the kind of "radical departure from our current energy path" seen as necessary yet hitherto impossible, then the IEA has shown its ability to help make the case for just such a change.

Third, the IEA's expert input into the climate convention has supported and strengthened the work of the UNFCCC Secretariat, for example with regard to establishing reliable GHG emissions inventories, the UNFCCC's expert policy review process or its technical examination process. This positive interaction of key players in the energy and climate fields, respectively, has brought about a greater integration between the two governance architectures.

Fourth, the impact of the IEA's change advocacy is not to be underestimated. Following Bauer's (2009) work on "advocacy bureaucracies", we contend that the IEA's advocacy influence can be seen as both cognitive and executive. The IEA's arguments in support of disruptive policy change and the sustained framing of tackling anthropogenic global climate change as a necessary step in the transition to a sustainable energy future have had a cognitive impact on numerous other actors by reducing ambiguity over core concepts and particular policy solutions, focusing attention and keeping the issue on the agenda. Critically, the arguments raised by publications such as the WEO and statements by the IEA's Chief Executive and Chief Economist are increasingly in line with those made by leading actors in the global climate negotiations. Research on the impact of message framing conducted in a variety of fields has long recognized that source credibility makes a difference to people's willingness to accept a product or argument (see e.g. Benford and Snow, 2000; Grewal et al., 1994; Mahon and Wartick, 2003). Both the high organizational credibility of the IEA in the energy field and the credibility of those officials engaging in the advocacy 
(such as Fatih Birol) mean that the message is more likely to get accepted by target audiences than if it had come from other sources. For example, the impact of IEA data and reports on climate negotiations is amplified precisely because it is the IEA as a perceived "independent body" providing "heavy-hitting evidence" in support of rapid decarbonization rather than an environmental organization. ${ }^{33}$

Beyond this cognitive influence, however, the IEA's impact is also of an executive nature. The Agency has long been the "standard international point of reference for data and analysis in world energy markets" (Van de Graaf, 2012: 236), but the annual WEOs' growing focus on climate change issues has also had direct implications for ministerial officials involved in global climate negotiations. Starting in 2009, publication of the WEO increasingly became a "regular date in the diary for climate change negotiators" which provided "incredibly helpful ammunition used in narratives with different countries." 34 The IEA's change advocacy - with both its cognitive and executive impacts - has helped the Agency adapt to a changing environment while lending greater credibility to those arguing for a rapid decarbonization of the global economy.

However, a key challenge arises from the IEA's lack of directive influence over the energy policy decisions of its member countries. The IEA gathers statistics, recommends, advises and, as shown above, advocates certain courses of action but it cannot compel individual members to pursue particular policies, for example firmer GHG emissions targets or renewable energy support schemes, not least as such decisions are inextricable from important contestations and disputes in energy and climate policy direction. This restricts the ability of the IEA, and similar international organizations, such as IRENA, to turn into a reality the low-carbon future its leading officials are advocating.

Further, while the IEA might be respected as a source of information and a political partner among the many emerging economies in the Global South, membership - and hence the right to vote - remains restricted to members of the OECD, that is, the traditional industrialized countries in the North, along with some richer Southern countries that have joined the OECD in recent years. Given the rapid growth of GHG emissions in non-member countries, this creates a challenge for the IEA in its attempt to bridge divides between energy and climate governance beyond the confines of the OECD. ${ }^{35}$

\footnotetext{
${ }^{33}$ Interview with former senior UK negotiator to the climate convention, March 2015.

34 Ibid.

${ }^{35}$ It is worth noting here that emissions embedded in goods manufactured outside the OECD (e.g.in China or India) but consumed within it are not currently accounted for in the domestic production-based GHG emissions
} 
Thus far the IEA has been able to effectively work with other countries and intergovernmental organizations without expanding its core membership. In recent years it has stepped up cooperation with major energy producers and consumers around the world, particularly its seven partner countries in the G20, namely China, India, Brazil, Mexico, Indonesia, South Africa and Russia, as well as with selected member states of ASEAN. This cooperation has gone beyond just the issuing of occasional reports. The seven G20 partner countries actively participate in the IEA Ministerial Meeting, which takes place every two years to set broad strategic priorities for the Agency. The IEA's statistics courses, for instance, are designed for and regularly attended by government representatives from non-member countries. In late 2013, the IEA and its partner countries (with the exception of Mexico) issued a Joint Declaration on Association which stated their mutual interest "to pursue closer cooperation on the basis of a common understanding that global energy challenges and energy security require shared solutions by producer, consumer and transit countries" (IEA, 2013b). The planned association would be an important further step towards expanding the IEA's reach beyond its traditional OECD membership.

But whether or not these partnerships can be formalized to further expand the IEA's influence, its cooperation with the UNFCCC and IRENA means that the Agency is already working, either directly or indirectly, with countries that are not currently among its members. Therefore, from the perspective of integrated governance approaches to energy and climate change, an enlargement of the IEA's membership is perhaps not necessary in the current situation.

\section{Conclusion}

Global governance efforts have, to date, proven woefully inadequate to tackle the growing impact of human activities on the atmosphere, biosphere, geosphere and hydrosphere. The effective mitigation of global climate change is a monumental task, requiring nothing less than the "fundamental reorientation and restructuring of national and international institutions toward more effective earth system governance and planetary stewardship" (Biermann et al.,

individual countries report to the UNFCCC. As with most other organizations gathering emissions statistics, the IEA also collates data on a domestic production basis. It is generally accepted that a full accounting would increase the GHG emissions profiles of industrialized countries, with serious implications for international climate negotiations. For a thorough discussion of consumption-based accounting of emissions see, for example, Davis and Caldera (2010) and Bruckner et al. (2010). 
2012: 1306). The first necessary step of such a reorientation and restructuring is better integration of existing governance architectures in order to overcome the compartmentalization between the energy and climate change fields that has contributed to the lack of progress in drastically cutting GHG emissions. As we have shown, the IEA's changing activities in recent years - broadening its issue portfolio, increasing its cooperation and partnership with the UNFCCC and IRENA, and advocating for a transition to a lowcarbon future - demonstrate that such integration is well underway. And yet, extant scholarship of both global energy governance and global climate governance has thus far been largely inattentive to such emergent integration. This is in part because energy and climate policy - at both domestic and international levels - has long evolved largely separately from each other, and, relatedly, so has the academic literature on these fields. However, with policy making in relation to energy and climate change becoming increasingly and deeply inter-connected, it behooves scholarship in each of these fields to be closely attentive to developments in the other. Indeed, as our analysis of the IEA's changing activities shows, neglecting either dimension distorts understanding of both.

The recent activities of the IEA we have discussed are a manifestation of changes the organization is undergoing as it engages with and adapts to a complex and dynamic global policy environment. Apart from closing gaps and creating further synergies between the IEA and key organizations in both global energy and global climate governance, these activities are also positioning the integration of energy and climate change itself as a central issue in both. In this way, they represent concrete steps towards the convergence of global policies and practices, the need for which is commonly acknowledged but has not been widely acted upon. The developments are not only beneficial from the perspective of effective climate change mitigation, but also hold two key implications for the IEA as an organization. First, they strengthen the Agency's role going further into the $21^{\text {st }}$ century. No serious international organization operating in the energy field today can do so without addressing climate change and the rise of renewable energy sources. The IEA is cementing its role in the field, in the process demonstrating its ability to respond effectively to past criticism and positioning itself to respond to future challenges. Second, the IEA's recent activities are extending its influence well beyond the global energy governance field. The closer cooperation between the IEA and the climate convention has turned the IEA into a partner upon whose technical and policy expertise the UNFCCC Secretariat has come to rely. While the IEA does not (intend to) lead climate negotiations, it plays an increasingly important role within this process. Taken 
together these are quite a turn for an international organization whose founding role was to coordinate responses to oil supply disruptions.

\section{References}

Adelman, M. A., 1973. American import policy and the world oil market. Energy Policy, 1(2), pp. 9199.

Atalay, Y., et al., 2016. Adoption of renewable energy policies in oil-rich countries: Explaining policy variation in the Gulf Cooperation Council states. Renewable Energy, 85, pp. 206-214.

Bamberger, C., 2004. The History of the International Energy Agency, 1974-2004 - Volume 4: Supplement to Volumes 1, 2 and 3. Paris: OECD/IEA, < http://www.iea.org/media/4_ieahistory.pdf > [accessed 17.1.2013].

Barnett, M. N., Finnemore, M., 1999. The politics, power, and pathologies of international organizations. International Organization, 53(4), pp. 699-732.

Barnett, M. N., Finnemore, M., 2004. Rules for the world: International organizations in global politics. Cornell University Press, Ithaca.

Bauer, S., 2009. The Desertification Secretariat: A Castle Made of Sand. In: Biermann, F., Siebenhüner, B. (Eds.), Managers of Global Change: The Influence of International Environmental Bureaucracies. The MIT Press, Cambridge, pp. 293-318.

Baumgartner, F.R., Jones, B.D., 1993. Agendas and Instability in American Politics. University of Chicago Press, Chicago.

Beckman, K., 2014. 'Gradual change will not save us.' Interview with Fatih Birol, IEA. Energy Post, June 3, <http://www.energypost.eu/interview-fatih-birol-iea-gradual-change-will-save-us/> (05.8.2014).

Benford, R.D., Snow, D.A., 2000. Framing Processes and Social Movements: An Overview and Assessment. Annual Review of Sociology, 26, pp. 611-639.

Bernauer, T., 1995. The Effect of International Environmental Institutions: How We Might Learn More. International Organization, 49(2), pp. 351-77.

Biermann, F., 2014. Earth System Governance: World Politics in the Anthropocene. MIT Press, Cambridge, MA.

Biermann, F., Siebenhüner, B. (Eds.), 2009. Managers of Global Change: The Influence of International Environmental Bureaucracies. The MIT Press, Cambridge.

Biermann, F. et al., 2009a. International Organizations in Global Environmental Governance. Routledge, London. 
Accepted (pre-proof) manuscript of: Heubaum, Harald and Biermann, Frank, 2015. Integrating global energy and climate governance: The changing role of the International Energy Agency, Energy Policy 87, pp. 229-239.

Biermann, F. et al., 2009b. The Fragmentation of Global Governance Architectures: A Framework for Analysis. Global Environmental Politics, 9(4), pp. 14-40.

Biermann, F. et al., 2010. The architecture of global climate governance: setting the stage. In: Biermann, F. et al. (Eds.), Global Climate Governance Beyond 2012. Architecture, Agency and Adaptation. Cambridge University Press, Cambridge, pp. 15-24.

Biermann, F. et al., 2012. Navigating the Anthropocene: Improving Earth System Governance. Science, 335(6074), pp. 1306-1307.

BP, 2014. Statistical Review of World Energy 2014. <www.bp.com/statisticalreview> [accessed 10.11.2014].

Bruckner, M. et al., 2010. Counting CO2 emissions in a globalised world: Producer versus consumeroriented methods for CO2 accounting. Discussion Paper. German Development Institute, Bonn.

Bulkeley, H., Newell, P., 2010. Governing Climate Change. Routledge, London.

Bulkeley, H. et al., 2014. Transnational Climate Change Governance. Cambridge University Press, Cambridge.

Burck, J. et al., 2015. The Climate Change Performance Index: Results 2015. Germanwatch / Climate Action Network Europe.

Cherp, A. et al., 2011. Governing Global Energy: Systems, Transitions, Complexity. Global Policy, 2(1), pp. 75-88.

Chester, L., 2010. Conceptualising Energy Security and Making Explicit its Polysemic Nature. Energy Policy, 38(2), pp. 887-895.

Clark, D., 2012. Phasing out fossil fuel subsidies 'could provide half of global carbon target.' The Guardian, January 19, <http://www.theguardian.com/environment/2012/jan/19/fossil-fuelsubsidies-carbon-target> [accessed 15.1.2013].

Colgan, J., 2009. The International Energy Agency: Challenges for the 21st Century. Berlin: Global Public Policy Institute, GPPi Policy Paper Series No. 6.

Colgan, J., 2014. The Emperor Has No Clothes: The Limits of OPEC in the Global Oil Market. International Organization, 68(3), pp. 599-632.

Damanpour, F., 1991. Organizational innovation: A meta-analysis of effects of determinants of moderators. Academy of Management Journal, 34, pp. 555-590.

Damanpour, F., Evan, W. M., 1984. Organizational Innovation and Performance: The Problem of “Organizational Lag”. Administrative Science Quarterly, 29(3), pp. 392-409.

Damanpour, F., Schneider, M., 2006. Phases of the adoption of innovation in organizations: Effects of environment, organization and top managers. British Journal of Management, 17, pp. 215-236.

Davis, S.J., Caldeira, C., 2010. Consumption-based accounting of CO2 emissions. Proceedings of the National Academy of Sciences of the United States of America, 107(12), pp. 5687-5692. 
Accepted (pre-proof) manuscript of: Heubaum, Harald and Biermann, Frank, 2015. Integrating global energy and climate governance: The changing role of the International Energy Agency, Energy Policy 87, pp. 229-239.

Energy Next, 2014. Renewables a bright spot in decarbonising energy system. <http://www.energynext.in/maria-van-der-hoeven-2/> [accessed 05.8.2014].

Epps, T., Green, A., 2010. Reconciling Trade and Climate: How the WTO Can Help Address Climate Change, Edward Elgar, Cheltenham.

Escribano, G., 2015. Fragmented Energy Governance and the Provision of Global Public Goods. Global Policy, 6(1), pp. 1-9, DOI: 10.1111/1758-5899.12195.

Falkner, R., 2008. Business power and conflict in international environmental politics. Palgrave Macmillan, Basingstoke.

Falkner, R., 2014. Global environmental politics and energy: mapping the research agenda. Energy Research \& Social Science, 1, pp. 188-197.

Florini, A., 2010. The International Energy Agency in Global Energy Governance. Global Policy, 2(S1), pp. 40-50.

Florini, A., Sovacool, B., 2009. Who governs energy? The challenges facing global energy governance. Energy Policy, 37(12), pp. 5239-5248.

Ford, L., 2003. Challenging global environmental governance: social movement agency and global civil society. Global Environmental Politics, 3(2), pp. 120-134.

Fouquet, R. (Ed.), 2013. Handbook on Energy and Climate Change. Edward Elgar, Cheltenham.

Garcia, S. M. et al. (Eds.), 2014. Governance of Marine Fisheries and Biodiversity Conservation: Interaction and Coevolution. John Wiley \& Sons, Chichester.

Gately, D. et al., 2013. The rapid growth of OPEC's domestic oil consumption. Energy Policy, 62, pp. 844-859

Goldthau, A., 2011. Governing Global Energy: Existing Approaches and Discourses. Current Opinion in Environmental Sustainability, 3(4), pp. 213-217.

Goldthau, A. (Ed.), 2013. The Handbook of Global Energy Policy. Wiley-Blackwell, Oxford.

Goldthau, A.,Witte, J.-M., 2010. Global Energy Governance: The New Rules of the Game. Brookings Institution Press, Washington, D.C.

Grewal, D. et al., 1994. The Moderating Effects of Message Framing and Source Credibility on the Price-perceived Risk Relationship. Journal of Consumer Research, 21(1), pp. 145-153.

Gupta, J., 2014. The History of Global Climate Governance. Cambridge University Press, Cambridge.

Haas, P.M. et al., 1993. Institutions for the Earth: Sources of effective international environmental protection. The MIT Press, Cambridge.

Hage, J., 1988. The Futures of Organizations. Lexington: DC Heath.

Hage, J., 1999. Organizational innovation and organizational change. Annual Review of Sociology, 25 , pp. 597-622.

Hannan, M., Freeman, J., 1984. Structural inertia and organizational change. American Sociological Review, 49, pp. 149-64. 
Accepted (pre-proof) manuscript of: Heubaum, Harald and Biermann, Frank, 2015. Integrating global energy and climate governance: The changing role of the International Energy Agency, Energy Policy 87, pp. 229-239.

Harvey, F., 2012a. Governments failing to avert catastrophic climate change, IEA warns. The Guardian, April 25, <http://www.theguardian.com/environment/2012/apr/25/governmentscatastrophic-climate-change-iea> [accessed 15.1.2013].

Harvey, F., 2012b. Coal to challenge oil's dominance by 2017, says IEA. The Guardian, December 18, 〈http://www.theguardian.com/environment/2012/dec/18/coal-challenge-oil-international-energyagency) [accessed 15.01.13].

Held, D. et al. (Eds.), 2011. The Governance of Climate Change: Science, Economics, Politics and Ethics. Polity Press, Cambridge.

Held, D. et al., 2013. Climate Governance in the Developing World. Polity Press, Cambridge.

Helm, D. (Ed.), 2005. Climate-change Policy. Oxford University Press, Oxford.

Helm, D., Hepburn, C. (Eds.), 2009. The Economics and Politics of Climate Change. Oxford University Press, Oxford.

Hirschl, B., 2009. International renewable energy policy - between marginalization and initial approaches. Energy Policy, 37(11), pp. 4407-4416.

Hochman, G., Zilberman, D., 2015. The political economy of OPEC. Energy Economics, 48, pp. 203216.

Hoffmann, M. J., 2011. Climate Governance at the Crossroads: Experimenting with a Global Response After Kyoto. Oxford University Press, Oxford.

Howlett, M., et al., 2009. Studying Public Policy: Policy Cycles and Policy Sub-systems, $3^{\text {rd }}$ Edition. Oxford University Press, Oxford.

IEA, 2010. World Energy Outlook 2010. OECD/IEA, Paris, <http://www.worldenergyoutlook.org/media/weo2010.pdf> [accessed 15.1.2013].

IEA, 2012a. Energy Technology Perspectives 2012: Pathways to a Clean Energy System. OECD/IEA, Paris, <http://www.iea.org/publications/freepublications/publication/ETP2012_free.pdf> [accessed 17.1.2013].

IEA, 2012b. Collaboration between IEA, UNFCCC will lead to improved data and analysis on climate issues. Press Release. September 26,

<http://www.iea.org/newsroomandevents/news/2012/september/name,31627,en.html> [accessed 22.1.2013].

IEA, 2012c. Statement by International Energy Agency Executive Director on COP 18. December 3, $<$ http://www.iea.org/newsroomandevents/news/2012/december/statement-by-internationalenergy-agency-executive-director-on-cop-18.html> [accessed 6.1.2013].

IEA, 2013a. Redrawing the Energy-Climate Map. World Energy Outlook Special Report. OECD/IEA, Paris, <http://www.iea.org/publications/freepublications/publication/WEO_Special_Report_2013_Redr awing_the_Energy_Climate_Map.pdf> [accessed 09.11.2014]. 
Accepted (pre-proof) manuscript of: Heubaum, Harald and Biermann, Frank, 2015. Integrating global energy and climate governance: The changing role of the International Energy Agency, Energy Policy 87, pp. 229-239.

IEA, 2013b. Joint Declaration by the IEA and Brazil, China, India, Indonesia, Russia and South Africa on the occasion of the 2013 IEA Ministerial Meeting expressing mutual interest in pursuing an association. November 20, <http://www.iea.org/newsroomandevents/ieaministerialmeeting2013/jointdeclaraction.pdf > [accessed 05.8.2014].

IEA, 2014a. Energy Technology Perspectives 2014: Harnessing Electricity's Potential. OECD/IEA, Paris.

IEA, 2014b. Technology Roadmap: Solar Photovoltaic Energy. OECD/IEA, Paris.

IEA, 2014c. Technology Roadmap: Solar Thermal Electricity. OECD/IEA, Paris.

IEA, 2014d. Taking on the challenges of an increasingly electrified world. Press Release. May 12, $<$ http://www.iea.org/newsroomandevents/pressreleases/2014/may/taking-on-the-challenges-ofan-increasingly-electrified-world-.html> [accessed 05.8.2014].

IEA, 2015a. Energy and Climate Change. World Energy Outlook Special Report. OECD/IEA, Paris.

IEA, 2015b. Global energy-related emissions of carbon dioxide stalled in 2014. Press Release. March 13, <http://www.iea.org/newsroomandevents/news/2015/march/global-energy-related-emissionsof-carbon-dioxide-stalled-in-2014.html> [accessed 02.4.2015].

IEA, 2015c. IEA sets out pillars of success at COP21. Press Release. June 15, $<$ http://www.iea.org/newsroomandevents/pressreleases/2015/june/iea-sets-out-pillars-forsuccess-at-cop21.html> [accessed 15.6.2015].

IEA/NEA, 2015. Technology Roadmap: Nuclear Energy. OECD/IEA, Paris.

IPCC, 2014. Climate Change 2014: Synthesis Report. Contribution of Working Groups I, II and III to the Fifth Assessment Report of the Intergovernmental Panel on Climate Change. IPCC, Geneva, Switzerland.

IRENA, 2012. New IRENA-IEA partnership will heighten technology and innovation co-operation. Press Release, January 16, $<$ http://www.irena.org/News/Description.aspx?NType=A\&PriMenuID=16\&catid=17\&News_ID $=173>$ [accessed 6.1.2013].

Johannessen, J., et al., 2001. Innovation as newness: what is new, how new, and new to whom? European Journal of Innovation Management, 4(1), pp. 20-31.

John, P., 2003. Is there life after policy streams, advocacy coalitions, and punctuations: using evolutionary theory to explain policy change? Policy Studies 31(4), pp. 481-498.

Kohl, W. L., 2010. Consumer country energy cooperation: the International Energy Agency and the global energy order. In: Goldthau, A., Witte, J.-M. (Eds.), Global Energy Governance: The New Rules of the Game. Brookings Institution Press, Washington D.C, pp. 195-220.

Kingdon, J.W., 2002. Agendas, Alternatives, and Public Policies, $2^{\text {nd }}$ Edition. Longman, New York. Kruyt, B. Et al., 2009. Indicators for energy security. Energy Policy, 37(6), pp. 2166-2181. 
Accepted (pre-proof) manuscript of: Heubaum, Harald and Biermann, Frank, 2015. Integrating global energy and climate governance: The changing role of the International Energy Agency, Energy Policy 87, pp. 229-239.

Lamprinakis, L., 2012. Organizational Innovation and Institutional Change: The Case of Valio in Finland. International Journal on Food System Dynamics, 3(2), pp. 95-105.

Leal-Arcas, R. et al., 2015. International Energy Governance: Selected Legal Issues. Edward Elgar, Cheltenham.

Lesage, D. et al. (Eds.), 2010. Global Energy Governance in a Multipolar World. Ashgate, Farnham. Leverett, F., 2010. Consuming energy: Rising powers, the International Energy Agency, and the global energy architecture. In: Alexandroff, A.S., Cooper, A.F. (Eds.). Rising States, Rising Institutions: Challenges for Global Governance. Brookings Institution Press, Washington, D.C., pp. 240-265.

Levitt, B., March, J. G., 1988. Organizational Learning. Annual Review of Sociology, 14, pp. 319340.

Mahon, J.F., Wartick, S.L., 2003. Dealing with Stakeholders: How Reputation, Credibility and Framing Influence the Game. Corporate Reputation Review, 6(1), pp. 19-35.

Mason, J., Ennis, D., 2009. G20 agrees on phase-out of fossil fuel subsidies. Reuters, September 26, <http://uk.reuters.com/article/2009/09/26/us-g20-energy-idUSTRE58O18U20090926>, [accessed 12.3.2015].

Meyer, T., 2013. The Architecture of International Energy Governance. American Society of International Law Proceedings, 106, pp. 389-394.

Murray, J., 2009. IEA accused of "deliberately" undermining global renewables industry. BusinessGreen, January 12, <http://www.businessgreen.com/bg/news/1806340/iea-accuseddeliberately-undermining-global-renewables-industry> [accessed 15.1.2013].

Nachmany, M., et al. (2014). The GLOBE Climate Legislation Study: A Review of Climate Change Legislation in 66 Countries. $4^{\text {th }}$ Edition. GLOBE International and the Grantham Research Institute, London School of Economics: London.

O’Neill, K., 2009. The Environment and International Relations. Cambridge University Press, Cambridge.

Oberthür, S., Stokke, O. S. (Eds.), 2011. Managing Institutional Complexity: Regime Interplay and Global Environmental Change. The MIT Press, Cambridge.

Pattberg, P. H., 2007. Private Institutions and Global Governance: The New Politics of Environmental Sustainability. Edward Elgar, Cheltenham.

Peters, G.P. et al., 2012. The challenge to keep global warming below $2^{\circ} \mathrm{C}$. Nature Climate Change, 3 , pp. 4-6.

REN21 (Renewable Energy Policy Network for the 21st Century), 2012. Renewables 2012 Global Status Report, Paris: REN21 Secretariat, <http://www.ren21.net/ren21activities/globalstatusreport.aspx> [accessed 22.1.2013]. 
Accepted (pre-proof) manuscript of: Heubaum, Harald and Biermann, Frank, 2015. Integrating global energy and climate governance: The changing role of the International Energy Agency, Energy Policy 87, pp. 229-239.

Sabatier, P.A., Jenkins-Smith, H.C., 1993. Policy Change and Learning: An Advocacy Coalition Approach. Westview Press, Boulder.

Scott, R., 1994. The History of the International Energy Agency, 1974-1994, Volume 2: Major Policies and Actions. OECD/IEA, Paris, <https://www.iea.org/media/2ieahistory.pdf> [accessed 27.12.2012].

Scott, R., 1995. The History of the International Energy Agency, 1974-1994, Volume 3: Principal Documents. OECD/IEA, Paris, <https://www.iea.org/media/3ieahistory.pdf> [accessed 27.12.2012].

Sovacool, B., Brown, M., 2010. Competing Dimensions of Energy Security: An International Perspective. Annual Review of Environment and Resources, 35, pp. 77-108.

Sprinz, D. F., Helm, C., 1999. The Effect of Global Environmental Regimes: A Measurement Concept. International Political Science Review, 20(4), pp. 359-369.

Stevenson, H., Dryzek, J. S., 2014. Democratizing Global Climate Governance. Cambridge University Press, Cambridge.

Surrey, J., 1974. Japan's uncertain energy prospects: the problem of import dependence. Energy Policy, 2(3), pp. 204-230.

UNFCCC, 1997. Kyoto Protocol to the United Nations Framework Convention on Climate Change, <http://unfccc.int/resource/docs/convkp/kpeng.pdf> [accessed 15.1.2013].

Urpelainen, J., Van de Graaf, T., 2015. The International Renewable Energy Agency: a success story in institutional innovation? International Environmental Agreements, 15, pp. 159-177.

Van Asselt, H., 2014. The Fragmentation of Global Climate Governance: Consequences and Management of Regime Interactions. Edward Elgar, Cheltenham.

Van Asselt, H., Zelli, F., 2014. Connect the dots: managing the fragmentation of global climate governance. Environmental Economics and Policy Studies, 16(2), pp. 137-155.

Van de Graaf, T., 2012. Obsolete or resurgent? The International Energy Agency in a changing global landscape. Energy Policy, 48, pp. 233-241.

Van de Graaf, T., 2013a. The Politics and Institutions of Global Energy Governance. Palgrave, Houndmills.

Van de Graaf, T., 2013b. Fragmentation in Global Energy Governance: Explaining the Creation of IRENA. Global Environmental Politics, 13, pp. 14-33.

Van de Graaf, T., Lesage, D., 2009. The International Energy Agency after 35 years: reform needs and institutional adaptability. The Review of International Organizations, 4(3), pp. 293-317.

Van der Hoeven, M., 2015. With Adnan Amin in \#Berlin. Tweet. March 26, <https://twitter.com/VanderHoeven_M/status/581131254646628352>, [accessed 30.3.2015].

Victor, D.G., Kennel, C.F., 2014. Ditch the $2^{\circ} \mathrm{C}$ warming goal. Nature, 514(7520), pp. 30-31. 
Wapner, P., 1995. Politics Beyond the State: Environmental Activism and World Civic Politics. World Politics, 47(3), pp. 311-340.

Westall, S., Dahl, F., 2011. Oil price could strangle economic recovery hopes - IEA. Reuters, November 24, <http://www.reuters.com/article/2011/11/24/us-oil-ieaidUSTRE7AN12020111124> [accessed 15.1.2013].

Wettestad, J., 1999. Designing Effective Environmental Regimes: The Key Conditions. Edward Elgar, Cheltenham.

Wittmann, N., 2013. OPEC: How to transition from black to green gold. Energy Policy, 62, pp. 959965.

World Bank, 2014. Turn Down the Heat: Confronting the New Climate Normal. World Bank, Washington, DC.

Yergin, D., 2011. The Quest: Energy, Security and the Remaking of the Modern World. Allen Lane, London.

Young, O.R., 1989. International Cooperation: Building Regimes for Natural Resources and the Environment. Cornell University Press, Ithaca.

Zelli, F., 2011. The Fragmentation of the Global Climate Governance Architecture. WIREs Climate Change 2011, 2, pp. 255-270.

Zelli, F. et al., 2013. Global Climate Governance and Energy Choices. In: Goldthau, A. (Ed.). Handbook of Global Energy Policy. Wiley-Blackwell, Chichester, pp. 340-357. 